\begin{tabular}{|c|c|c|c|c|c|c|c|c|c|c|c|c|c|}
\hline \multicolumn{14}{|c|}{ TABLE V. } \\
\hline Hour & 4 & 5 & 6 & 7 & 8 & 9 & ro & II & 12 & 13 & 14 & 15 & Average \\
\hline$H N$ & 0 & 0 & $\circ$ & $\circ$ & o & 3 & 4 & $r_{3}$ & 5 & o & $\circ$ & $\circ$ & $2 \cdot 2$ \\
\hline lN & $\circ$ & II & $x_{4}$ & 24 & 22 & $\begin{array}{r}3 \\
12\end{array}$ & 25 & 22 & $x 1$ & II & 0 & o & $15^{\circ} \circ$ \\
\hline$N$ & 8 & 37 & $3 I$ & 26 & 22 & 19 & 21 & 9 & II & 0 & $\circ$ & 33 & $19^{-8}$ \\
\hline$N h$ & 8 & 5 & 6 & 2 & 3 & 0 & 7 & o & 0 & $\circ$ & $\circ$ & 0 & $2 \%$ \\
\hline$N h-Z$ & 8 & o & 3 & $\mathrm{I}^{2}$ & 9 & 9 & 7 & $\circ$ & $\circ$ & 5 & 13 & o & 6.2 \\
\hline$N h-S Z$ & 8 & 5 & 6 & $x^{2}$ & 16 & 19 & 4 & 9 & 5 & II & 25 & o & $10 \cdot 3$ \\
\hline$Z$ & ० & 0 & 0 & 2 & $\epsilon$ & o & 7 & 0 & 0 & 5 & 13 & o & $2 \cdot 6$ \\
\hline$S Z$ & $\circ$ & $\circ$ & 3 & 2 & $\circ$ & 3 & o & $\circ$ & $\circ$ & o & o & o & $r \cdot I$ \\
\hline$S h$ & 8 & o & 0 & 5 & 0 & 0 & 0 & $\circ$ & $\circ$ & $\circ$ & $\circ$ & o & $I^{\prime} I$ \\
\hline$S$ & 8 & o & o & 2 & $\circ$ & 3 & 4 & 。 & 5 & o & $\circ$ & $\circ$ & 1.8 \\
\hline$t \div(N+S)$ & 8 & o & 3 & $\circ$ & 3 & 6 & o & $\circ$ & 5 & o & $\circ$ & 。 & $2 \cdot 2$ \\
\hline$t \div i s$ & 0 & 5 & o & 2 & 3 & 9 & 4 & 9 & 5 & 16 & $\circ$ & $\circ$ & 48 \\
\hline$t \div I N$ & $\circ$ & o & $\circ$ & 2 & o & 0 & $\circ$ & 0 & $\circ$ & $\circ$ & $\circ$ & $\circ$ & 0.4 \\
\hline$N+S$ & 8 & $\circ$ & 6 & 2 & 6 & 3 & 4 & 9 & 5 & o & $\circ$ & $\circ$ & $4 \%$ \\
\hline$t$ & 8 & II & 6 & 5 & $\circ$ & 6 & 4 & $x_{3}$ & XI & 5 & 13 & $\circ$ & $6 \cdot 2$ \\
\hline o & 25 & 26 & 23 & 12 & 9 & 3 & II & I7 & 37 & 47 & 38 & 67 & $19 \%$ \\
\hline$N^{\prime}$ & 25 & 53 & 54 & 53 & 56 & 47 & 64 & 43 & 26 & 16 & $x_{3}$ & 33 & $46 \cdot 2$ \\
\hline$S^{\prime}$ & 17 & $\circ$ & 3 & 9 & $\circ$ & 6 & 4 & 0 & 5 & 0 & $\circ$ & 0 & 40 \\
\hline$t^{\prime}$ & 23 & 16 & 20 & 26 & 34 & 44 & $2 \mathrm{I}$ & 39 & $3^{2}$ & 37 & 50 & o & $30 \% 4$ \\
\hline$S^{\prime}+t^{\prime}$ & 50 & 16 & 23 & 35 & 34 & 50 & 25 & 39 & 37 & 37 & 50 & o & $34 \cdot 4$ \\
\hline
\end{tabular}

TABLE VI.

\begin{tabular}{|c|c|c|c|c|c|c|c|c|c|c|c|c|}
\hline Hour & 4 & 5 & 6 & 7 & 8 & 9 & ro & II & 12 & $I_{3}$ & I4 & Tctal \\
\hline $\begin{array}{l}I j \\
I S \\
I j s \\
I I j \\
I I s \\
I I j s \\
I I I \\
V \\
I=j \\
I=s \\
I=j s \\
I I=j \\
I I=s \\
I I=j s\end{array}$ & $\begin{array}{c}3 \cdot 3 \\
0 \\
3 \cdot 3 \\
0 \\
0 \\
0 \\
0 \\
0 \\
0 \\
0 \\
3 \cdot 3 \\
0 \\
3.3 \\
6.7 \\
\end{array}$ & 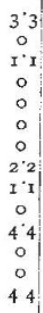 & \begin{tabular}{c|c|}
4 & 6 \\
0 \\
1 & 5 \\
0 \\
0.8 \\
0 \\
0.8 \\
$1 \cdot 5$ \\
2.3 \\
0.8 \\
$1 \cdot 5$ \\
$1 \cdot 5$ \\
0.8 \\
2.3
\end{tabular} & 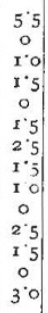 & $\begin{array}{c}4.0 \\
0 \\
20 \\
0 \\
0 \\
27 \\
0.7 \\
17 \\
07 \\
07 \\
07 \\
27 \\
0 \\
07 \\
40 \\
40\end{array}$ & $\begin{array}{c}29 \\
0 \\
2 \cdot 4 \\
0 \\
06 \\
1 \cdot 2 \\
0.6 \\
r^{2} 2 \\
x^{2} 2 \\
0 \\
2 \cdot 9 \\
0 \\
0.6 \\
3.5\end{array}$ & 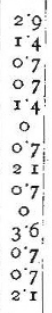 & $\begin{array}{c}0.8 \\
x \cdot 7 \\
2.5 \\
x \cdot 7 \\
0 \\
0.8 \\
3.3 \\
2.5 \\
0 \\
0.8 \\
2.5 \\
1.7 \\
0 \\
0.8\end{array}$ & $\begin{array}{cc}2 & 2 \\
1 & 1 \\
2 & 2 \\
1 & 1 \\
0 & 1 \\
0 & 1 \\
1 & 1 \\
I & I \\
3 & 3 \\
0 & \\
0 \\
2 \cdot 2 \\
0 \\
I \cdot I \\
0\end{array}$ & \begin{tabular}{c|c|}
$r$ & 3 \\
0 \\
$r$ & 3 \\
$r$ & 3 \\
$r$ & 3 \\
$r$ & 3 \\
$r$ & 3 \\
$r$ & 3 \\
5 & 0 \\
0 \\
0 \\
$r \cdot 3$ \\
0 \\
0 \\
0
\end{tabular} & \begin{tabular}{|c|c|}
0 \\
2 & 0 \\
0 \\
2 & 0 \\
0 \\
0 \\
0 \\
20 \\
0 \\
0 \\
0 \\
0 \\
40 \\
20 \\
0
\end{tabular} & $\begin{array}{r}30^{\circ} 8 \\
6.2 \\
18.0 \\
8.3 \\
4^{\circ} .1 \\
8.6 \\
111^{\circ} 0 \\
22.6 \\
7.0 \\
20^{\circ} 3 \\
26.9 \\
9.4 \\
9.2 \\
26.8\end{array}$ \\
\hline $\begin{array}{c}I \\
I I \\
j \\
s \\
j s\end{array}$ & $\begin{array}{r}100 \\
3.3 \\
3.3 \\
13.3 \\
13.3\end{array}$ & $\begin{array}{c}4.4 \\
44 \\
0 \\
10^{\circ}\end{array}$ & 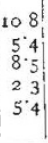 & $\begin{array}{r}\text { ro. } \\
7.5 \\
9.5 \\
0.5 \\
0 \\
8.0\end{array}$ & $\begin{array}{r}\text { ro.0 } \\
7.3 \\
47 \\
4.3 \\
\text { II } 3\end{array}$ & \begin{tabular}{rr|}
9 & 4 \\
5 & 9 \\
4 & $\mathrm{r}$ \\
$\mathrm{r} \cdot 2$ & 2 \\
10 & 0
\end{tabular} & $\begin{array}{l}9 \cdot 3 \\
5 \cdot 7 \\
5 \cdot 0 \\
3 \cdot 6 \\
6 \cdot 4\end{array}$ & $\begin{array}{l}8.3 \\
5.0 \\
4.2 \\
25 \\
6.7\end{array}$ & \begin{tabular}{ll|}
7 & 8 \\
3 & 3 \\
3 & 3 \\
3 & 3 \\
5 & 3 \\
5 & 6
\end{tabular} & $\begin{array}{l}3.8 \\
3.8 \\
2.5 \\
1.3 \\
3.8\end{array}$ & $\begin{array}{l}20 \\
80 \\
60 \\
40 \\
0\end{array}$ & $\begin{array}{l}90^{\circ} \cdot 4 \\
66.3 \\
55.5 \\
22.8 \\
80.5\end{array}$ \\
\hline
\end{tabular}

On the valuable isochasme chart, in which Prof. Fritz has denoted the increasing frequency of the aurora borealis northwards, the maximum zone of the phenomenon falls far south of Iceland. I must, however, first explain what my definition of the word maximum zone is at present. It is a line passing across the places where the aurora not only appears and is most frequently visible, provided the weather permits, but where it also, as a rule, appears in zenith, or as often on the northern as the southern hemisphere. According to this definition, the correctness of which I think can neither be disputed nor doutted, Iceland lies, at all events this year, as was the case with Kautokeino and Bossekop last year, considerably south of the maximum zone, which is, in fact, clearly shown in Table V.

I hope to be able to demonstrate this in a more conclusive manner still on a future occasion, when the winter is over and the numerous exact determinations of the southern border of the aurora borealis will be discussed.

The reason why the maximum zone lies so far south on Prof. Fritz's chart may be sought, perhaps, in the circumstance that the climatic conditions of Iceland to a great extent reduce the number of auroræ which an ordinary observer, who only casually or on particular occasicns looks at the sky, may observe. That the maximum zone of the aurora does not really fall across the part shown in the chart is also distinctly apparent from what I learnt of its appearance at the Färoe Islands during my sojcurn there.

It may perhaps be superfluous to state that neither here nor in any other place have I heard the mystic auroral sound. Neither has it ever been heard by any of the Icelanders I have as yet met with.

Shortly before leaving Copenhagen last autumn I spoke with a celebrated Danish savant, who had some years ago spent some time in Reykjavik, and $v$ ho told me that he had on several occasions seen auroræ descend below and in front of the mountain Esja, about 2500 feet in height, and lying six to seven English miles away (NATURE, vol. xxix. p. 337). I was de- lighted with the prospect of being able to see a similar pbenomenon, as, although my observations in the plane Bossekop. Kautokeino, previously referred to, had greatly contributed to strengthen my belief in the height of the aurora borealis being $100 \mathrm{~km}$, or more above the earth (NATURE, vol. xxix. p. 4I2), I would with pleasure have accepted a proof so tangible pointing in ar other direction. I regret to say that my expectations have not been fulfilled. This is not kecause the aurora has not been in close proximity to Esja, as, the mountain lying to the north-east from this place, nearly all ares and bands rise with their eastern end up behind and run above it, but never have $I$ been so fortunate as to see any auroral light descend to the top of the mountain or in front of its steep sides. Even the highestlying clouds are also, in Iceland, below the plane of the aurora borealis.

In connection with this point I may further mention that the faint luminosities referred to by Prof. Lemström above the mountain-tops at Sodankylä, and in other places (NATURZ, vol. xxvii. p. 322), as well as phenomena of a similar nature have, I venture to assert, never been observed here. I have continually had my attention directed to this point, and there are several mountains here, but $I$ have never been able to trace the slightest indication of such a phenomenon.

I brought with me the necessary apparatus and appliances for effecting such experiments as Prof. Lemström pursued on some mountains in Northern Finland for the production of an artificial aurora borealis, and shortly after my arrival I came to the conclusion that the above-mentinned mountain Esja was the most advantageous for such. Its great height, steep fall into the sea, and short distance from the town, were advantages such as no other spot in the district offered, but as I only brought with me $1000 \mathrm{~m}$. of insulated wire-telegraph-poles with insulators cannot be employed in consequence of the nature of the ground -and wished to conduct the wire from the top of the mountain down 10 the sea at its foot, I was obliged to wait until I obtained more wire by the steamer at the end of November. Since then the execution of this plan has been attempted a number of times; men, boats, and horses have heen ready, and everything prepared, but every time the unfortunate weather has frustrated the same. Even in the middle of summer the Esja is a mountain difficult to ascend, and at this time of the year it would be very dangerous to undertake an ascent with the heavy wires, insulators, and poles, without the weather being remarkably quiet for several days.

I intend, however, very shortly to make another attempt, and should this fail I will select a more distant but much lower and more unfavourably situated mountain top. I will only add that a few days after my arrival I fixed one of Prof. Lemström's "utströmnings" apparatus-with 200 points-on the flat roof of a stone tower, 30 to 40 feet in height, and which lies free and isolated on a heiuht in the vicinity of the town; but the same has up to the present, in spite of numerous trials, given no result whatever. Any current between the points and the earth cannot be traced, and of any luminous phenomena above them there has not been the faintest appearance. SOPHUS TrOMHOLT

Reyljavik, February

\section{ON THE NATURAL AND ARTIFICIAL FERTILISATION OF HERRING OVA ${ }^{1}$}

IN 1862 Prof. Huxley arrived at the conclusion that herring visit our shores in order to spawn twice a year, some schools arriving during the autumn, while others make their appearance during the winter. The herring which spawn during the autumn chiefly frequent banks on the east coast, while those which spawn during winter are most abundant on the west coast. A report of the Scottish Fishery Board referring to the east coast spawning beds was published in NATURE on November 29 last. The present paper deals chiefly with the Ballantrae spawning bed, which lies off the coast of Ayrshire.

In 1862 Prof. Allman made some investigations for the Scottich Fishery Board, and succeeded in dredging and hatching what was considered herring ova ; but since then, although important results have been obtained by the German and American Commissioners of Fisheries, little or nothing has been done in this country.

When examining the Ballantrae Bank the author of this paper succeeded in dredging several specimens of herring ova aitached

I Abstract of a paper read by Prof. J. Cossar Ewart, M.D., at the Royal Society, March 27. Communicated by the Author. 
to stones, seaweed, and sea-firs. These stones coated with eggs varied from 6 inches $t$ ) $1 \frac{1}{2}$ inches in length, and from 4 inches to $\mathrm{I}$ inch in breadth, but in all cases the eggs were attached to a comparatively smooth surface, and they were arranged either in low cones or in comparatively thin layers one or two eggs deep. The eggs on the sea-firs were always attached in small clusters about half an inch in diameter around the stems. On examining the spawn found on the stones and seaweed, embryos at various stages of development were at once visible, some of them apparently only three days old, while others had distinct eyes, and from their violent movements and their size seemed almost ready for hatching. Some of the eyg-coated stones weie taken to the University of Edinburgh, where the eggs hatched on March 15, eight days after their removal from the spawning ground, and today (March I7) they are three-eighths of an inch in length, extremely active, and swimming freely about in the water.

By taking soundings over the Ballantrae Bank in various directions, it was ascertained that it $\mathrm{c}$ nsisted of rock, stones, shells, and coarse sand, and that the depths varied from 7 to $I_{3}$ fathoms. The outer edge of the bank shelved at most points rapidly until a depth of $I 7$ fathoms was reached, and at this depth the bottom consisted of fine, soft mud. While on the east coast spawning grounds examined during the autumn the surface temperature in most cases varied from $53^{\circ} \mathrm{F}$. to $55^{\circ} \mathrm{F}$, and the bottom temperature from $52^{\circ} \mathrm{F}$. to $54^{\circ} \mathrm{F}$., even at a depth of 40 fatho ns, the temperature at the Ballantrae Bank varied from $42^{\circ} \cdot 8$ to $43^{\circ} .8 \mathrm{~F}$. at the surface, and from $43^{\circ} .5$ to $42^{\circ} \cdot 8 \mathrm{~F}$. at the bottom. The corres, 0 onding surface temperature, however, on the east coast during the week ending March 8 was from $2^{\circ}$ to $3^{\circ} \mathrm{F}$. lower than at Ballantrae.

According to previous observers -

"When spawning takes place naturally, the egys fall to the bottom and attach themselves." "But at this time the assembled fish dart wildly about and the water becomes cloudy with the shed fluid of the milt. The eggs thus become fecundated as they fall, and the development of the young within the ova sticking to the bottom commences at once."

Mr. Mitchell, in his book on " The Herring," referring to the once famous spawning bed off Dunbar, states that-

"A bout August 30 the shoals began to deposit their spawn a short distance from the harbour, and on September 3 the fishermen found that a very large body of herrings remained fixed to the ground in the progress of spawning, the ground being of a rocky or stony nature."

While many fishermen believe that herring spawn on hard ground, some believe that they also spawn on a clayey bottom; and while some think they spawn near the botton, others affirm that they spawn near the surface. Having secured at Ballantrae a large number of live herring, so ne of the laryest and ripest males and females were placed in a large wooden tank into which a number of stones an 1 a qu untity of seaweed had been previously introduced. After the fish had been about two hours in this tank, the stones and seaweed were examined. Although a few e ggs.were attached to both stones and seaweed, it was quite evideat that the eggs had not been deposited in the same way as those found on the stones dredged on the previous day; but we were not surprised that only a few isolated eggs were found on the stones, bzcau ie the fish had been disturbed every few minutes by the pouring of water into the tank.

On reaching Rothesay the hatching boxes and live herring were at once transferred from H.M.S. Fackal to the tanks-a tank into which comparatively little light entered being selected for the ri i est and $m$ sst vigorous herring. In about half an hour after they were introduced a large full herring was seen moving sl wly about the bottom of the tank with four other fish making circles around her at some distance from the bottom. Appe iring satisfied with a particular stone which she had evidently been examining, she halted over it and remained stationary for a few minutes about half an inch from its surface, the tail being in a straight line with the tank and the pectoral fins near or resting on the bottom.

Whil in this position a thin, beaded ribbon was seen to escape from the genital opening and fall in graceful curves on the surface of the stone, so as to form a slightly conical mass almost identical with a cluster on one of the stones dredged at Ballantrae. As this little heap of eggs increased-some falling to the left side one moment, while others fell to the right the next, accordin $x$ to the currents in the water-the males continued circling round her at variou; distances, while the other females in the tan's remained apart. The males remained from 8 to $x 0$ inches above the botton of the tank, and formed circles varying from 18 inches to 2 feet 6 inches in dianeter. Some of the males were swimming fro $n$ right to left, others from left to right; and altbough there was no darting about, no struggling amongst them ielves, there was a peculiar jerking of the tail as they performed their revolutions. Soon the object of this peculiar movement was sufficiently evident. Three or four times during each revolution each fish expelled a small white ribjon of milt, whi sh varied from half an inch to three-quarters of an inch in length, and was nearly a line in breadth across the centre, but pointed at both ends, and somewhat thinner than it was broad. These delicate ribbons slowly fell through the water, sometimes reaching the bottom almost undiminished in size, but in most instances they had almost completely dispersed before the botiom was reached. In this way the whole of the water about the female became of a very faint milky colour, and practically every drop of it was charged with sperms, as was afterwards a certained. It will thus be seen that there is no attempt whatever on the part of the males to fertilise the eggs as they e; cape from the female. While the female is depositing the eggs at the butt.m, the males concern themselves with fertilising the water in the neighbourhood, and it will be observed that the males are careful to guard against the influence of currents by forming circles around the female and shedding milt on the way. It matters little how the currents are running, they are bound to carcy some of the milt towards the egss, the milt, like the eggs, sinking though not aihering to the bottom.

This then is the natural process of depositing and fertilising the ova of the herring in comparatively still water. When the female had dsposited a certain number of exgs at any given spot, she moved forward in a somewhat jerky fashion without rising from the bottom, and as she changed her position the males changed theirs, so tbat the female was always surrounded by a fine rain of short sperm ribbons. A specimen of Hydrallmannia sent from Eyemouth seeins to indicate that the female moves about amongst sea-firs and seaweeds in exactly the same way as she does amongst stones. On each stem of the culory there is a clu ter of ova about the size of a small grape, and all the clusters had reached on arrival the same stage of develo;ment as if they had been deposited about the same time and by the same fin.

This methol of depositing and fertilising the eg ss accounts, I think, for all the eggs, or at least for a very large percentage of those found attached to sea-firs, seaweeds, and stone;, containing developing embryos.

When a female was depositing her eggs, she was very easily disturbed; whenever anything was introduced into th: tank she at once darted off. When strong currents were made, she at first seemed to apply herself nearer to the bottom, to make sure, as it were, that the spawn would get fixed before it could be carried away; but when the currents were further intensified she at once chan ged her position, and arrested the escape of the spawn. A spawning female was held immediately under the surface of the water so as to cause the spawn to e.scape. When this was done the spawn escaped in long ribbons consisting of a single row of egys. So firmly do the eggs adhere to each other that in perfectly still water the ribbon was sometimes over a fost in length before it broke. When it had only about two feet of water to travel tbrough, it fell in wide loops at the bottom, but when it had to fall over three feet the chain broke up into numerou; segments which formed an irregular pattern on the bottom. From experiments made, it seems the further the eggs have to fall and the longer they are in contact with the water bef re they reach the bottom, they are more widely disparsed, and have all the le is adhesive power. When the eg ss are expressed in water moving rapidly in varions directions, the chains soon break into short segments, and the individu il eggs and the small groups are often carried a considerable distance before they reach the bott. on.

A number of flat stones and pieces of se zweed were obtained, and a spawning female held over them at different distances in still water, in water with gentle currents, and in water with strong currents. In this way we obtained groups of eggs which mimicked in a very striking manner all the arrangements of the eggs on the stones and seaweeds dredged on the Ballantrae Bank. When gently pressed, a beaded ribbon consisting of a single row of egrs always escaped; when there were no currents, it formed a conical heap; when in a gentle current, the ribbo: fell in irregular loops, the elements of which rearranged thenselves so as to form a flattened cone; but when strong currents acted on it the ribbon wa; broken ints fragnents 
and only a few eggs succeeded in fixing themselves to the objects introduced. When the currents were strong, the miles were seen not only to swim nearer the bottom but to expel longer ribbons of milt, which reached the bottom before getting dispersed and remained visible sometimes for ten minutes. On gently expresing a male under the water it was never pos.ible to expel so fine or so short portions of milt as escaped naturally, but it was extremely eacy expelling a ribbon from 18 inches to 3 feet in length, measuring 2 lines across and I line in thickness. Such ribbons fell to the bottom and remained almost unchanged for nearly two hours; they then assumed a segmented appearance, and in about three hours and a half had all but disappeared.

Eggs were allowed to escape into a vessel containing fine sand, and into another containing mud. The eggs after being fertili ed underwent the early stages of development, but either owing to their moving freely about with the sand particles or owing to their getting coated over with the sand and mud their development was arrested. I have not yet determined finally if the development is arrested when the eggs are detached while development is proceeding, but this seems extremely probable.

When at Ballantrae I noticed that the trammel nets secured often more males than females. Mr. Wilson, fishery officer at Girvan, informs me that the ripe-t fish are caught in the trammel net; while mo it of the unripe fish are obtained in the drift nets, and that at the end of the fishing season there are about three males taken for every two females, indicating not necessarily that the males are more abundant than the females, but rather that the males remain longer on the spawning ground; and Mr. Wilson believes that herring prefer quiet water free from strong currents when spawning, and that when the weather is fine the herring remain long upon the bank and deposit their spawn leisurely, but when there are strong currents they either hurry the spawning process or disappear into deep water.

As to artificial fertilisation and hatching I found, after many experiments at Ballantrae, that the best results were obtained when both the male and female were held under water while the milt and ova escaped, i.e. when the natural process of spawning is followed.

An ordinary wooden tub was obtained and filled with seawater. Into this a small quantity of milt was expressed, the male being held completely under water while the milt escaped. A glass plate was then held about four inches beneath the surface of the water, and, the female herring being held about one inch beneath the surface, by gentle pressure the eggs readily escaped in the characteristic narrow beaded ribbon, and, by moving the fish over the surface of the glass, either a close or an open network could be formed. At first, where one loop crossed another, the eggs were two or more layers thick, but, either owing to the weight of the eggs or the gentle currents set up in the water, before a few ninutes had elapsed, the eggs formed a single and almost continuous layer, the network arrangement having disappeared. The plate was then allowed to rest for two or three minutes at the bottom of the tub, and a few short ribbons of milt were again introduced. After moving the plate once or twice across the top of the tub in order to wash off any scales that were adhering, it was placed either in a hatching or a carrying box. Many thousands of ova treated in this way contain extremely active embryos, which are expected to hatch on March 22 or 23.

Prof. Ewart exhibited a number of specimens showing herring eggs attached to stones, seaweeds, and sea-firs, and some of the herring fry batched on March 24 from the eggs artificially fertilised on March 8.

\section{UNIVERSITY AND EDUCATIONAL INTELLIGENCE}

OXFORD. - The electors have awarded the Radcliffe Travelling Fellowship after examination to Mr. J. E. Blomfield, B.A., late Natural Science Demy of Magdalen College, and now of University College Hospital, London. The Fellowship is of the annual value of $200 \%$., and tenable for three years provided that the Fellow travels abroad for his improvement in the study of mericine. This is the fourth time in the last five years that this prize Fellowship has been won by a student of Magdalen College.

CAMBRIDGE.-From the report of the last Local Examina. tions it appears that the answers in pure mathematics exhibited considerable improvement, while in applied mathematics the work was inferior, and much of the teaching in statics was imperfect, and not based on mathematics. In chemistry great inequality was shown, some centres sending uniformly good work, others being very inferior. The practical work is better done than the theoretical. The teaching of experimental physics is still very ineffectual in its results. In the senior paper in elec. tricity and magnetism only two of the candidates showed any proof of accurate knowledge or scientific training.

In biology the answers were, on the whole, not good, yet at some centres candidates did extremely well. In botany vegetable pbysiology showed improvement, but floral diagrams are not sufficiently used. In zoology the candidate: seemed to have no idea of the relative value of facts. In physical geography a marked absence of scientific method was noticeable in the answers; great ignorance of meteorological terms used in most daily papers was manifested.

The Cambridge Local Lectures have made good progress in the past session, much good having resulted from the conference of local committees and lecturers held last year. In a number of centres local associations have been formed for putting the lectures on a permanent basis. At Derby an Artisans' Higher Education Society has been formed, the subscription being very low. At the Midland Railway works the large mess-rooms have been utilised in giving short lectures to arouse interest among the men, Prof. Teall lecturing on chalk, Mr. Bemrose on the transit of Venus, Mr. Heycrck on digestion, respiration, \&c., and the men have always been appreciative. In the Newcastle district much eagerness has been shown by pitmen to attend the lectures, often at great personal cost and inconvenience. The cost, indeed, is s) great as to form an obstacle of serious magnitude, and it is found that the desire for lectures is such that the overcoming of financial difficulties would lead to an enormous ex. tension of the work. Efforts are being made to get the rules of the Trades Unions altered so as to enable them to contribute towards the cost of the lectures.

It is now proposed to constitute an examination in French or in German as the additional subjects required of candidates for honours degrees, unless the candidates choose rather to pass the General Examination for the B.A. degree. This change would be welcomed by the large number of students to whom the study of works in French and German would be an important aid in their Tripos subjects.

\section{SCIENTIFIC SERIALS}

THE Fournal of Botany for March contains the conclusion of Mr. T. Hick's valuable paper on protoplasmic continuity in the Florideæ. In quite a number of distinct genera belonging to this class he has now traced connecting threads between the proto. plasm from cell to cell. He regards these threads as permanent and essential structures, normally present in all parts of the thallus from the oldest to the youngest, not restricted to special localities and special cells.-Some details of the life-history of a rare and little-known British plant, Lithospermum purpureocaruleum, are contributed by Mr. Jas. W. White.

American Fournal of Science, March.-Experimental determination of wave-lengths in the invisible prismatic spectrum, with plate, by S. P. Langley. - The Quaternary gravels of Northern Delaware and Eastern Maryland, with map, by Frederick D. Chester. From a careful survey of this region the author infers that the peninsula became depressed at least 350 feet towards the close of the Glacial period, when the estuary thus formed received the discharge of the Delaware River, which pushed its way across the present States of Delaware and Maryland to the head of the Chesapeake. By this current and the subsequent distributing action of the waves the red gravel was deposited. Later on the land began to rise, the violence of the flood was abated, and the northern glacier gradually broke up. During this period the Philadelphia Clay was deposited, and the boulders distributed over the estuary by the icebergs from the glacier. The land continuing to rise, the shoal gravels were piled up by the waves and tides, the river began to assume its present channel, and the Delaware and Chesa. peake were finally parted.-On the identity of scovillite with rhabdophane, by G. J. Brush and S. L. Penfield.-A theory of the recent sun-glows, by H. A. Hazen. The author at. tributes the phenomena to the presence of watery vapour, ice 